\title{
Winery regions as the oldest cultural landscapes: remnants, signs, and metamorphoses
}

\section{Abstract}

Considering the general typology of landscapes, winery landscapes are a subtype of agricultural landscapes. A winery landscape is an area in which the dominant land use or indigenous vegetation consists of extensive grapevine crops, that is, vineyards and/or areas covered by wild grapevines; where a specific wine culture has evolved, or grapes constitute an important part of the local diet. In this paper, winery landscapes are studied at two levels: typological (as a repeatable, specific type of area with precisely defined characteristic features), and regional (regional areas that are unique and individual). The authors analyze the evolution of winery landscapes over time and describe their natural and historical aspects. A wide range of factors were taken into consideration: historical and political, socio-economic, cultural and religious influences, as well as the natural environmental background. This paper aims to describe the evolution of winery landscapes in Europe and beyond by considering the Mediterranean Basin, Asia Minor, Transcaucasia, and Central Asia.

Keywords

Winery landscape $\cdot$ cultural landscape $\cdot$ Vitis vinifera Mediterranean Europe $\cdot$ Central Asia

๑) University of Warsaw - Faculty of Geography and Regional Studies

\author{
Urszula Myga-Piątek, \\ Oimahmad Rahmonov \\ Faculty of Earth Sciences \\ University of Silesia in Katowice, Poland \\ e-mail: urszula.myga-piatek@us.edu.pl \\ e-mail: oimahmad.rahmonov@us.edu.pl \\ Received: 18 January 2018 \\ Accepted: 9 May 2018
}

\section{Introduction}

Describing the process of the formation of winery landscapes from the point of view of their evolution as well as transformation is difficult for a number of reasons. First of all, a difficulty results from the question: Do such landscapes actually exist? Or should we rather talk about winery regions, as mentioned in the title? As will be shown in this paper, these two terms are often treated as synonyms; so an appropriate methodological perspective needs to be set. Other problems include the extended period under analysis (the last 8 thousand years) and the necessity of relying on heterogeneous sources.

This paper reports on two kinds of analyses. One of these relates to the historical perspective and provides a temporal typology of landscapes in which vineyards dominate; and the other relates directly to the title of this paper and focuses on the transformation of selected regions as well as the spatial signs and remnants reflecting the use of land for the needs of viticulture.

The former analysis focuses on winery regions that are perceived to be part of,

- Natural landscapes: defined on the basis of their natural characteristics, taking into consideration the indigenous vegetation of an area, but not how the land has been acted upon by human culture in recent or historical times. This includes an analysis of the range of wild grapevines and the conditions in which they need to thrive (both in prehistoric times and afterwards);

- Historical landscapes: defined on the basis of the characteristics of the natural and cultural heritage of a given culture or civilization;
- Existing landscapes: defined on the basis of an analysis of the present characteristics of the natural environment, the use of land, and landscape physiognomy (characteristic features and landmarks);

- Forecasted landscapes: discussed with the specific scenario of climate changes in mind, as well as considering the influence of numerous cultural factors.

The authors have consciously decided to disregard here, potential landscapes, which are created with the hypothetical assumption that all human activity should stop in an area while natural processes are still at work (Chmielewski et al. 2015; MygaPiatek 2012). Such an analysis seems to be merely a theoretical exercise in this context, consequently, the goal of the paper does not justify taking it up.

In considering the general typology of landscapes, the term winery landscapes as used in this paper, is subordinate to agricultural landscapes. We could therefore describe a winery landscape as an area in which the dominant land use or indigenous vegetation consists of extensive grapevine crops, that is, vineyards and/or areas covered by wild grapevines, where a specific wine culture has evolved, or where grapes constitute an important part of the local diet. Regular, partly geometrical fields covered with grapevines constitute the so-called landscape background. In considering their physiognomy, the structural and functional (material) aspects, and the esthetic and symbolic aspects-that is, all the landscape's aspects-winery landscapes are a very distinctive subtype of agricultural landscapes. (Plit 
2011, 2016; Myga-Piatek 2012; Chmielewski et al. 2015). As with most agricultural landscapes, winery landscapes strongly depend on natural conditions (mainly climate, soil, and orography). Their development has also been influenced by numerous other cultural landscape-forming factors, which will be discussed in this paper. Consequently, winery landscapes may be studied on two levels:

- typological: a repeatable, specific type of area with precisely defined characteristic features (see the definition we have suggested above);

- regional: a unique, individual area, for example, winery regions such as Moslavina, Slavonia (and even their constituent micro-regions Kutjevo, Daruvar, OrahovicaSlatina, and Slavonski Brod), and Podunavlje with its subregions Baranja, Erdut and Srijem), etc. This uniqueness is additionally emphasized by endemic grapevine strains, which in some places receive their locale's name.

This dual approach to landscapes is indicated by the title of this paper, as we endeavor to combine an analysis of the spread of winery landscapes, a description of their objectives, and its repeatable characteristic features (i.e., 'typical' and, to some extent, common and universal); ${ }^{1}$ while, against this background, we identify specific 'islands,' that is, regions with highly individua or even unique characteristic features that constitute landscape determinants ${ }^{2}$ within specific regions (Myga-Piatek et al. 2015).

Winery landscapes are very individual in character, which results not only from the geometrical forms of grapevine plantations, but also from the highly specific architecture of accompanying winery buildings and other facilities. ${ }^{3}$ In many countries, vineyards are treated as a part of the cultural heritage and protected by law. They play a cultural role in keeping up traditions and regional identities. In English-language literature, the process of forming this type of landscape is called winery landscaping. ${ }^{4}$

The aim of this article is to describe the evolution of winery landscapes in Europe, while taking into consideration the Mediterranean Basin, Asia Minor, Transcaucasia, and Central Asia. The article is an initial attempt to analyze the expansion of winery landscapes and to identify some of the regularities in their transformations on the basis of the remaining traces and signs that are present in the landscape as well as in the material and non-material culture of local societies in selected areas. Traces refer here to fragments, remnants, scraps of space, but also to the extent of winery landscapes that have not been clearly delimitated. Signs, in turn, identify features, attributes, characteristics, and even landscape landmarks and determinants (in a material and physiognomic approach), as well as brands and emblems (in a symbolic and semantic approach).

The spatial scope of the paper covers Europe's warm, temperate climate zone and the landscape zone of deciduous forests. However, some areas in Western and Central Asia constitute a necessary background to our topic. This results from the fact that Vitis grapevines represent, according to botanists, three groups: North American, Asian (with about 30 species each), but only one Eurasian species, which had the biggest influence on spreading cultivation around the world (Komarov 1938).

Winery regions should be understood as large areas with regular, common, and long-lasting grapevine cultivation. Winery

'Except for the 'core' described here, the same features are also common for the winery landscapes of California, Chile, Argentina, Australia, and South Africa, which have formed since the colonial period.

2Disappearing landmarks may be one of the diagnostic features that help determine the borders of a given region (landscape determinants).

${ }^{3}$ World Landscape Architect 2017

${ }^{4}$ Henry Architects 2017 regions constitute a continuous landscape zone (Figure 1), whose reach within the area under analysis gradually moves north. It becomes more and more common to find small, scattered and often isolated grapevine patches (traces) among forests, agricultural land (of different character), mosaic landscapes, or even suburban landscapes, north of this continuous winery regions zone. Such patches result from the spontaneous decisions of landowners, some of whom may want to test the suitability of the environmental conditions for this sensitive plant. These experimental (to a certain degree) vineyards cultivate increasingly more resistant strains. Likewise, in contemporary Poland, the process of establishing new vineyards may be considered to be a kind of avant-garde process in agriculture, however, most vineyards result from the successful restoration of those that existed in the Middle Ages, for example in Lesser Poland (the so-called historical landscapes). ${ }^{5}$

\section{Sources and methods}

Our analysis is a secondary one; it is an attempt to collect and generalize the results of primary research in the fields of archeology, paleobotany, palynology (lake and biogenic sediments), history, paleoclimatology (Bouby \&Marinval 2001; Góralczyk 2016; Mangafa \& Kotsakis 1996; McGovern 2003), and ampelography (Jackson 2008). Analyses of grapevine remnants enable scientists to determine the areas where wild grapevines have grown, to trace the process of their domestication, to distinguish between the wild and domesticated varieties, and to follow cultivation methods and improvements in the technology of wine-making (Góralczyk 2016). Highly advanced laboratory methods, which were applied to material consisting of finds and fossils, enabled the analyses of grapevine ecotypes, and their range and popularity, as well as being able to trace the domestication processes. The finds, mostly in the form of grapevine seeds; preserved shoots, stems, trunks and even leaves; dried fruit and skins; remnants of individual grapes and whole clusters, often charred; and even pollen, have become objects of specialist research in the fields of archeobotany, palynology and paleobotany (Mangafa\&Kotsakis 1996; Renfrew 1996; Mc Govern 2003; Mc Govern et al. 1996; Myles et al. 2011). The increased proportion of organic material in archeological samples testifies to a sudden rise in the importance of grapevine cultivation and the popularity of grapevines as significant elements of the cultural landscape. It should be noted that advanced research in this area has already been carried out as early as the beginnings of the 20th century, when, inter alia, criteria, which enabled individual grapevine species to be distinguished on the basis of seed founds (such as Stummer's [1911] width/length index of seeds), were worked out. Important material for comparative research has been provided by artifacts such as presses used to squeeze out grape juice, barrels and ceramic containers for storing wine, drinking vessels, and devices that served to transport wine (e.g., from the Nile Valley). Their dating made it possible to describe in relatively great detail how grapevine cultivation spread and how the specificity of various winery regions developed (Góralczyk 2016).

In case of ancient times, significant material for analysis is provided by iconographic and heraldic data: preserved official stamps and emblems that document the process of wine-making (see Kaftari-Góralczyk 2016). Additional material may also come from artistic creations picturing grapevines and grapes, architectural details, as well as from notes written in cuneiform script on the oldest clay tablets in Mesopotamia during the second half of the 3rd millennium BCE (Zohary 1996). Relevant information (on the production and import of wine and raisins into the countries of

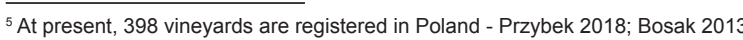




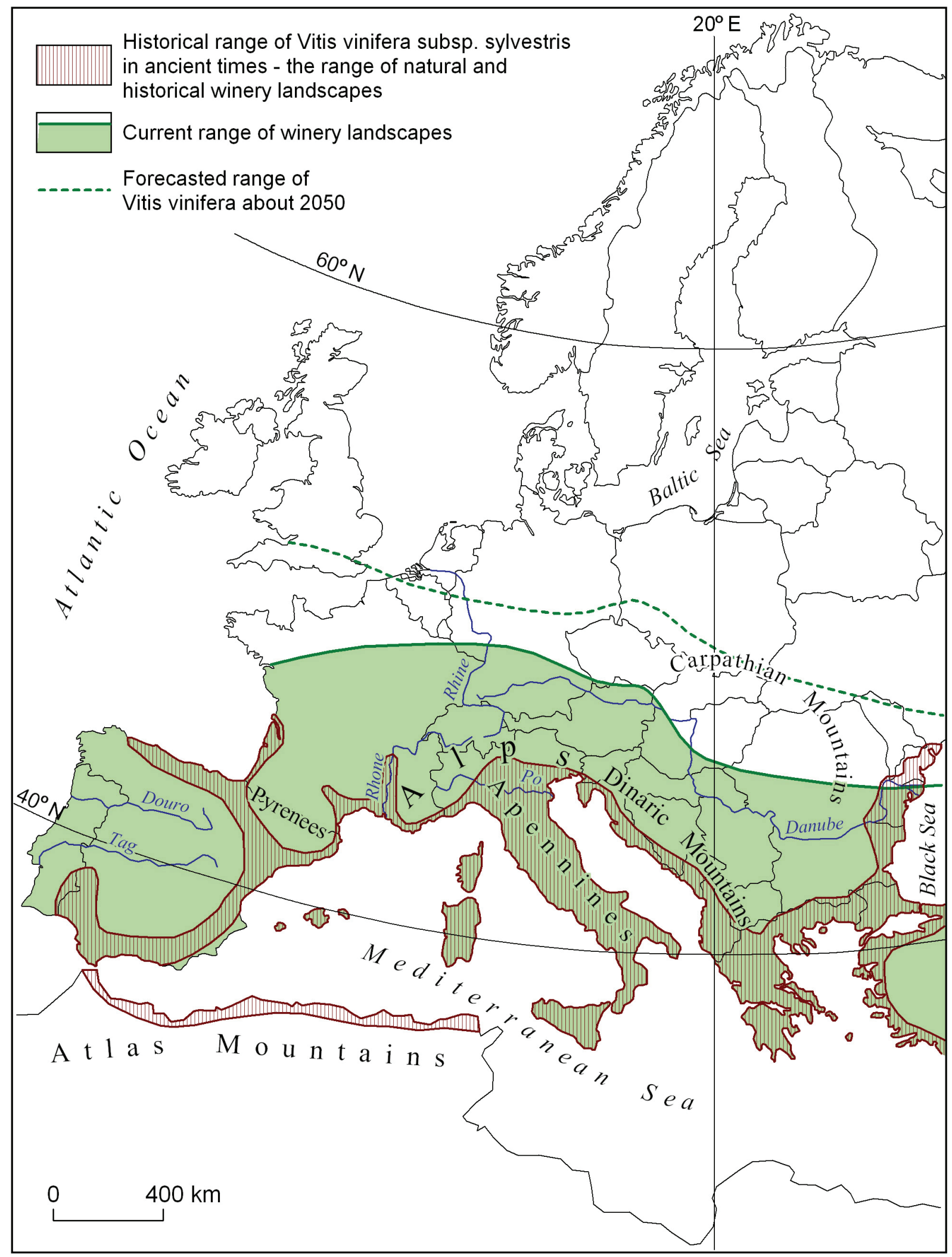

Fig 1. Winery landscapes of Europe Source: Own compilation 
the Levant) was also discovered in Egyptian hieroglyphic writings (Zohary 1996). Ancient writings created by the Sumerians, the Amorites, the Babylonians, the Chaldeans, and the Assyrians are currently under scientific scrutiny (Powell 1996; Zohary 1996). Thanks to the work of historians and paleobotanists, it is possible to identify the earliest venue of grapevine cultivation. Greek and Roman myths also provide some important clues. Interpretation of the cultural landscape in modern times has been significantly advanced by geohistorical sources, first of all, by the books of F. Braudel (2004) and B. Grabczewski (2012).

Our extensive literature survey shows the considerable role played by studies nowadays involving genetic material analyses, which is aimed at explaining how certain species emerged and how grapevines were domesticated, while also taking up topics such as the hybridization of plants and directions of their spread (e.g., Bacilieri et al. 2013; This, Lacombe \& Thomas 2006; Zinelabine et al. 2010). Additionally, many recent studies deal with the biochemical analyses of various grapevine strains (focusing mainly on anthocyanidins). These issues lie outside the scope of our analysis as they possess few links with the main topic.

This paper draws heavily on methods of landscape analysis, including evolutionary, factor analysis, and landscape stratigraphy (Myga-Piatek 2012). These were supplemented by observations and interviews carried out by the authors in many regions of the Mediterranean Basin and Central Asia. The paper provides a survey and a synthesis of existing research on the spreading of winery landscapes within the area under analysis.

\section{Natural landscapes}

Natural landscapes formed by the dominating Vitis vinifera subsp. Sylvestris originally covered large areas of the Mediterranean Basin and south-western Asia. This was the only representative of the Vitis genus in Europe and Northern Africa. During the Vistulian glaciation, it found refuge in Transcaucasia and the southernmost outskirts of Europe, that is, the Iberian Peninsula and Apennine Peninsula, where the greatest genetic diversity of this species is in evidence (in Italy, especially in Sicily). In historic times, wild grapevines grew in large areas of Southern Europe, from the territory of today's Spain, through Italy, Switzerland, Austria and Hungary, to Romania and the southern part of the Balkans. The map of Vitis' range includes areas from the coast of the Black Sea through the Caucasus to the southern coasts of the Caspian Sea (Figure 1). To the east, the range of the plant is delimitated by isolated patches in Uzbekistan and Tajikistan. Originally, the species grew in a wide range of habitats (Arroyo-García \& Revilla 2013; Heywood \& Zohary 1991).

In mild and moist climates the species spread north, typically settling on the outskirts of deciduous forests, where grapevines constituted a part of the local flora. During the Neolithic, wild grapes, together with other wild fruit such as figs, apricots, pears, and bitter almonds, were a valuable contribution to the diet of nomadic societies, and also later for early agricultural societies at the stage of settling down (Olmo 1996). Archeologists generally agree that from the earliest times some wild grapes were used for winemaking. Even today, wild grapevines appear south of the Caspian Sea, in the Balkans, and in the narrow coastal strip around the Mediterranean Sea, both in Europe and Africa, where grapevines cover the northern side of the Atlas Mountains, settling in deep valleys and moist gullies (Renefrew 1996; Zohary 1996) (see Figure 1). Thanks to its ability to adapt to difficult soil, climate, and orography, the plant may also be found among dry macchia scrubland in the Mediterranean region (Bouby \& Marinval 2001). The Vitis is a dioecious plant, and its fruit are the product of allogamy. It grows in the neighborhood of fields, small forests, and even on road shoulders and within secondary habitats up to $400 \mathrm{~m}$ and sometimes even $800 \mathrm{~m}$ above sea level, where many new varieties emerge these days from crossing with domesticated grapevines. Vines climb on trees up to a height of $30 \mathrm{~m}$ (Góralczyk 2016). There are numerous scientific publications in the fields of paleobotany and archeology that focus on the origin and spread of wild grapevines (referred to above). Such research may effectively help in determining the continuity of original winery landscapes (Heaton \& Merenlender 2000).

\section{Historical landscapes}

Historical winery landscapes emerged from the expansion of natural landscapes in which wild grapevines were the dominant form of local flora. Their earliest forms of these areas were covered by wild grapevines, which were used for food (and also, even then, for wine), and afterwards, areas settled by domesticated grapevines. In order to analyze historical landscapes, it is crucial to be aware of the environmental relations and cultural factors shaping the development of landscapes in a given period. As results of research carried out by the authors in relation to, inter alia, juniper forest landscapes in Central Asia, identifying the mutual ecological and anthropogenic influences plays a key role in the correct interpretation of landscape expansion and transformation processes (Rahmonov et al. $2017 \mathrm{a}, \mathrm{b}$ ).

In accordance with the landscape stratigraphy model proposed by Myga-Piatek (2012), very widespread historical winery landscapes may be classified into three subtypes:

- Continuous landscapes - ones that continue to exist, without any breaks, for thousands of years, for instance in Southern Europe (in countries such as Greece). From the point of view of stratigraphy, these landscapes are characterized by a very great thickness. In the Mediterranean they are among the oldest landscape subtypes. They are vertically homogenous, which results in horizontal homotony (cohesion and homogeneity of the landscape background). Such landscapes may be exemplified by well-established winery regions in which vineyards have been used continuously since historic times (Figure 1) - regions such as Toscana, Thrace, Epirus, the Peloponnese, Thessaly, Euboea, Macedonia, and Andalusia (Arroyo-García \& Revilla 2013).

- Disappeared landscapes - ones that were covered by vineyards in historic times, but where grapevine cultivation has stopped for various reasons. Landscape disappearance processes are often caused by natural phenomena such as a considerably colder climate (in Europe, the Little Ice Age 1350-1750), but also by historical and political factors. A good example are winery regions in Lesser Polandthat thrived from the beginnings of the Polish state until midfourteenth century, and disappeared afterwards (Bosak 2004; Myśliwiec 2009). Considering their vertical profiles, such landscapes changed their use completely over time, and were replaced by other landscapes, typically forest or agricultural land. They are heterogeneous and, depending on the subsequent forms of land use, either homotonic or heterotonic. (Figure 3).

- Revitalized landscapes - ones that are currently being reshaped through transformations and metamorphoses: vineyards are established either where they disappeared some time ago or in new venues with a different prior model of land use. Although rare, this also happens in the case of natural landscapes, where roots still remain in the soil (Bosak 2004; Myśliwiec 2009). The vertical profiles of such landscapes display no cohesion, and there are clear 'stratigraphic gaps' resulting from different land use (other landscape types). Revitalized landscapes are secondarily homotonic, or they may possess numerous elements and leftovers of 


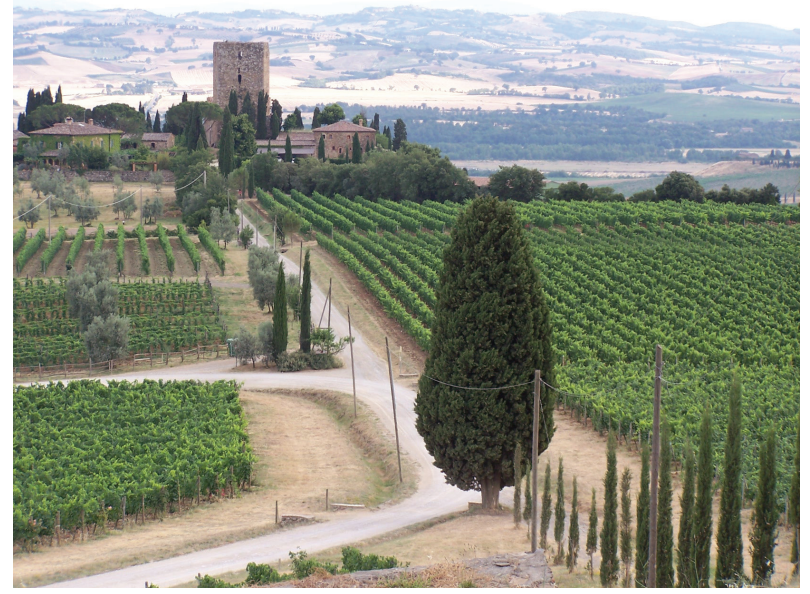

Figure 1. Current Tuscan landscape - an example of a continuous winery landscapes, Photo: U. Myga-Piątek

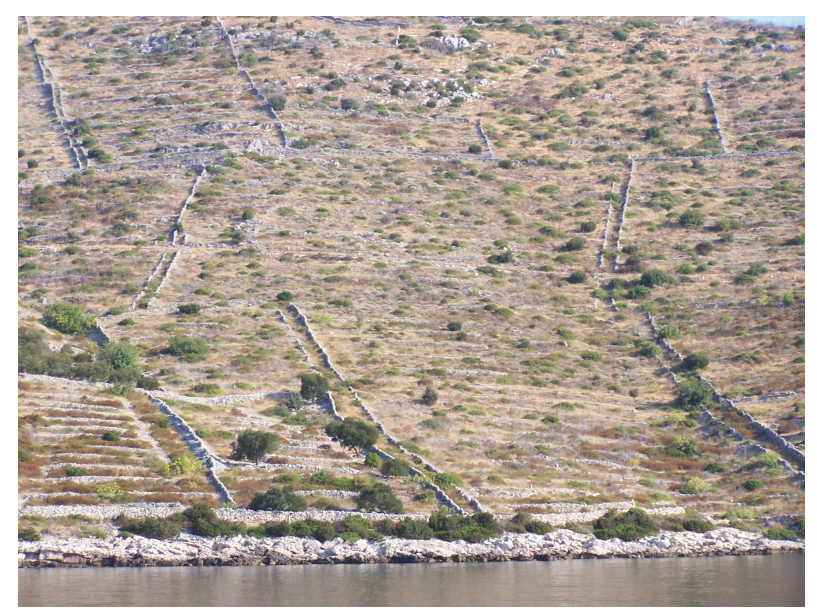

Figure 2. Extinct landscapes - The Dalmatian Coast, Photo: U. Myga-Piątek

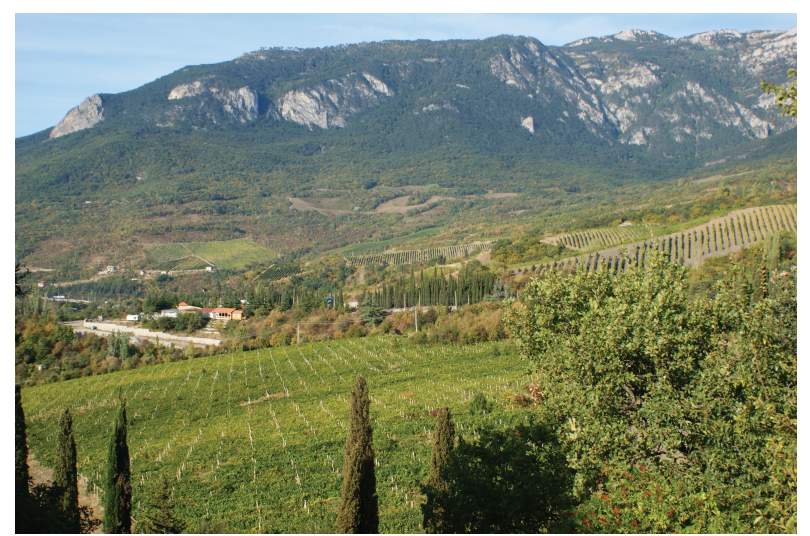

Figure 3. Revitalized landscapes - the surroundings of Segonzano, Trentino Alto Adige, Photo: U. Myga-Piątek other landscapes, which results in mosaicked, scattered landscapes with many traces and signs of grapevine cultivation in the past.

The evolution of historical winery landscapes on the basis of traces

The earliest traces of grapevine cultivation were identified on the basis of finds discovered during excavations, among other places, in Asia Minor. Works on reconstructing the extent of such cultivations were carried out at sites such as Nevali Çori near Urfa in the Euphrates Valley (finds dated to 8,400 BCE), Tell Aswad near Damascus, Tell Abu Hureyra in Syria, Korucutepe and Tepecik, Arslantepe, Kurban Höyük, Tell es-Sweyhat, Tell Hadidi and Tell Selenkahiyeh, Hammam et-Turkmen on the Balikh River in Syria, Tell Leilan on the Khabur River, and Tell Taya in northern Iraq (Zettler \& Miller 1996). Traces of tartaric acid discovered at the Hajji Firuz Tepe site north of the Zagros Mountains were, in turn, dated to the end of the 6th millennium BCE.

The oldest remnants of wild grapevines as well as archeobotanical evidence of grapevine domestication to be discovered in Europe come from continental Greece and Crete, and are dated at earlier than $6000 \mathrm{BCE}$. The continuity of winery landscapes in this area can be assumed from this. Excavations revealed the paleobotanical remnants of wild grapevines in Franchthi Cave in Argolis (from the Upper Paleolithic onwards); in Argissa, Achilleion and Sesklo in Thessaly (the Neolithic 1); in Sitagroi in Eastern Macedonia and Sesklo in Thessaly (the Neolithic 2); in Arapi, Dimini, Sesklo and Pefkakia in Thessaly; Dimitra, Dikili Tash and Sitagroi in Eastern Macedonia; Franchthi in Argolis (the Neolithic 3); in Sitagroi in Eastern Macedonia and Aghios Kosmas in Attica (Early Bronze Age); in Argissa and Pefkakia in Thessaly; Assiros in Western Macedonia; Athens in Attica; Knossos on Crete; Lerna in Argolis; Nichoria in Messenia and Orchomenus in Beotia (Middle Bronze Age); in Assiros and Kastanas in Western Macedonia; Dimitra in Eastern Macedonia; Iolkos in Thessaly; Kato Zachro and Knossos on Crete; Mycenae and Tiryns in Argolis, and Menelaion in Sparta (Late Bronze Age); in Assiros and Kastanas in Western Macedonia; Athens in Attica; Demetrias in Thessaly; and Samos in Eastern Aegean (Iron Age) (Renfrew 1996). In Spain, archeologists have dated cultivations to the Neolithic, about 3rd millennium BCE (Arnold et al. 1998; Nuñez-Rivera \& Walker 1989); and in Southern France, probably to the mid-Mesolithic (Bouby et al. 2010). An analysis of the oldest archeobotanical remnants discovered in Languedoc revealed that the same variety still grows in the area (Bouby et al. 2010). Paleobotanical and archeological research has shown that, in the Iron Age, when grapevines started being cultivated for wine in Southern France, wild and domesticated grapevines were still co-occurring there (Bouby et al. 2010, p.130). Wild varieties of grapevine were also grown outside the Mediterranean Basin, which is confirmed by archeological finds from Switzerland. They were discovered in sediments of the Neuchâtel and Léman Lakes and clearly show that wild grapevines grew on the banks of these lakes in the Bronze Age (Arnold et al. 1998; Desfayes 1989; Jacquat 1988).

Origin and expansion of winery landscapes

The grapevine (Vitis vinifera) belongs to the family Vitaceae, which comprises about 60 inter-fertile wild Vitis species that are distributed across Asia, North America, and Europe under subtropical, Mediterranean, and continental-temperate climatic conditions. It is the single Vitis species that has acquired significant economic interest over time; some other species, for example, the North American V. rupestris, V. riparia, or V. berlandieri, are used as breeding rootstock due to their resistance to grapevine pathogens (Terral et al. 2010), such as Phylloxera, Oidium, and 
mildews. It was a very good solution to generate resistance to Phylloxera with the use of American species, which were hybrids from rootstock, and many additional varieties of rootstock were developed by breeders (Arraigo \& Arnold 2007). The great majority of cultivars that are widely cultivated for fruit, juice, and mainly for wine (classified as Vitis vinifera L. subsp. vinifera [or sativa]), derive from wild forms (Vitis vinifera L. subsp. sylvestris [Gmelin] Hegi) (ed. Ovčinnikov 1981; Crespan 2004; This, Lacombe \& Thomas 2006). It should be emphasized that the distinction between wild and cultivated forms of Vitis vinifera $L$ is mainly based on morphological traits.

The process of domestication of Vitis vinifera $L$. has already been described, during the 1940s and 50s, by, among others, Negrul (1946) and Levdoux (1956). Archeologists emphasize how long the domestication process lasted and note that grapevine cultivation spread in an irregular manner. For instance, in Transcaucasia it started around the 8-6th millennium BCE; while on the coast of the Aegean Sea, in Mesopotamia, Syria and Egypt it was at the end of the 5th millennium BCE; and in Northwestern Iran, in the 4th millennium BCE. Around the 3rd millennium BCE, grapevine cultivation became common and reached beyond the habitat of wild grapevines (areas in today's Georgia, Armenia, and even Iran and Pakistan) - it was already popular in the Levant (inter alia, in the Jordan Valley and on the coast of the Dead Sea) (Zohary 1996). In the second half of 1st millennium BCE Greek colonizers brought grapevine cultivation to the southern parts of the Apennine Peninsula (Zohary 1996). In the first half of 1st millennium BCE, Phoenicians spread grapevine cultivation to the Maghreb (Terral et al. 2010). They are also believed to have done the same on the Iberian Peninsula (l'Alt de Benimaquia sites, Denia, Alicante). Both Phoenicians and Greek colonizers from Ampurias contributed to grapevine cultivation and winemaking in northeastern Spain (Bouby \& Marinval 2001; Nuñez-Rivera \& Walker 1989). In France, the development of vineyards started at the time of Greek colonization (about 600 BCE, when Marseilles was established by settlers from Phocaea), and from the 5th century BCE grapevine cultivation became common in Gallia Narbonensis (today's Provence and Languedoc). The expansion of the Roman Empire brought vineyards to the temperate climate zone of Europe, for example, the Rhine Valley (Zohary 1996). Other areas of grapevine cultivation we know of today became common from about 4th century CE, when Christianity was adopted in Europe (Terral et al. 2010; Góralczyk 2016).

The early Middle Ages can be regarded as the first stage in the development of cultural winery landscapes. Domestication of wild grapevines resulted in the relatively common tradition of establishing vineyards and producing wine in the Mediterranean. According to Jackson (2008) and McGovern, (2003), from the earliest times, wine was made from both wild and domesticated grapes, as both species grew in the same areas, although some specialization in production was already in evidence, and wine was still considered a luxury good and an object of international trade. As A. H. Joffe writes (1998), the consumption of alcoholic beverages was an important element of nutrition, feasting and hospitality rituals, and political economies in the early societies of Mesopotamia, Egypt, Syria, and the Levant.

Just as in the case of other plant species, grapevine domestication aimed to increase the crops and improve the taste of the fruit. During the 1st millennium BCE grapevines started being cultivated in northern and central Italy, France (Provence), Northern Africa, and Spain. The varieties growing there are not homogeneous, they were classified according to their ecotypes, which were verified thanks to research carried out in the Rhine Valley, the Danube Valley, and elsewhere. The first domesticated varieties were crossed with wild varieties (Bouby et al. 2010). There was also some hybridization between grapevine strains growing in neighboring areas. It is easier to reconstruct the origins of grapevine ecotypes from the more temperate zones of Europe: Portugal, France, and the Rhineland (Olmo 1996). Since ancient times, cultivation of grapevines has involved propagation using such methods as cuttings, layering, and grafting, but also sexual reproduction (Bouby et al. 2010, Olmo 1996). At present, nearly 10,000 cultivars stem from the wild species Vitis vinifera ssp. Sylvestris (Renfrew 1996).

An analysis of the spread of major grapevine varieties and strains may follow the classification proposed in the 1940s by Negrul (1946), who distinguished three groups of varieties. This typology is a very general one, and, according to modern specialists (Góralczyk 2016), it may even be selective and, consequently, incomplete; the Mediterranean, for instance, is missing. In fact, it is difficult nowadays to talk about the distinctiveness and homogeneity of winery regions that would result solely from their specialization in the cultivation of particular varieties and strains. The natural environmental conditions, including climate, have changed even in historical times, which results in hybridization and species migration. Furthermore, cultural factors, and primarily religious beliefs, have played a decisive role in spreading specialized grapevine varieties, that is, those suitable for wine-making and those producing fruit for immediate consumption or for raisins. Islam strongly influenced the selection of grapevine species that were cultivated in areas inhabited by Muslims with its preference for grapes that are only suitable for food. Resorting to a huge generalization and using classification examples given by Levadoux (1956) and Olmo (1996), it is possible to distinguish the following winery megaregions, which are characterized by their dominant grapevine varieties.

In Western Europe (France, Germany, Spain, and Portugal), the Occidentalis variety dominates. This variety is characterized by small but compact clusters of small, white or red grapes with medium sugar content and high acidity. This variety has been popularized with wine-making in mind, and it is very productive. Most strains are resistant to cold (Pinot noir, Riesling, Traminer, Aligoté, Gamay, Pinot, Chardonnay, Malingre précoce, Madeleine Angevine, Cabernet, Verdot, Sémillon, Sauvignon, Muscadelle, Folle blanche, Morrastel, Mourvèdre, Aléatico, Verdelho, Sercial, Oporto, Touriga, Albilho).

In Asia Minor as well as Greece, Romania, Georgia, Bessarabia, and Hungary, the Pontica variety is cultivated. Its clusters are also compact, medium-sized, and very juicy. The grapes' colors may vary from white to red or black. The variety is characterized by high acidity, and some strains are seedless. Its leaves have various shapes. Grapevines of this variety are mostly used for wine-making (Saperavi, Furmint, Hars Levelu, Vermentino, Clairette, Corinthe, Mtsvanie, Rka-Tsiteli, Saperavi, Alvarna, Kakur, Plavai, Chaouch, Dodrelabi).

In Central Asia, that is, Iran, Afghanistan, Armenia, and Azerbaijan, the Orientalis variety is cultivated. This variety needs very favorable climatic conditions, as it requires a long growing season and high temperatures. Scattered clusters create large and long bunches. The grapes are mostly white, fleshy and characterized by low acidity. The fruit is often seedless, so it is typically used for immediate consumption (Muslim countries). The strains include Thompson (Sultana), Muscat blanc à petits grains, Muscat d'Alexandrie, Cinsaut, Ohanes, Cornichon, Sultanine, Khalili, Charas, Katta-Kurgan, Rich Baba) (Levadoux 1956; Olmo 1996).

Factors causing metamorphoses of historical winery landscapes

Natural factors are the basis for winery landscape development. These are primarily the climatic factors (macroclimate, mesoclimate, and microclimate) as well as 
environmental conditions that exert significant influence on soil fertility, and determe where grape species can grow well. The most important climate factor is the annual atmospheric temperature range. This determines, inter alia, the so-called SAT $\left({ }^{\circ} \mathrm{C}\right)$ and $\mathrm{LTI}$ indexes that describe the ripening potential (Bokwa \& Klimek 2009) and the average temperatures in January and July. Other important factors are sunshine duration, air humidity, length of the growing season, occurrence of ground frost (and wet snow likely to break branches), annual rainfall distribution, snow cover, and general weather conditions during blooming and ripening. These factors are, at present, very well known (Bosak 1998, 2004, 2006).

Wild grapevines are heliophilous liana, and generally grow along river banks and in alluvial and colluvial deciduous and semi-deciduous forests (Levadoux 1956; Arnold et al. 1998). Physical and chemical soil properties, and their location in the landscape, play a key role in the development and vitality of a species, as well as its bioproductivity. The majority of species of the Vitis genera grow well in soil types such Haplic Leptosol (Calcaric), Calcic Chernozem, Mollic Gleysol (Colluvic), Haplic Luvisol, Mollic Fluvisol, or even Haplic Regosol according to WRB (2006) classification.

Winery landscapes in Central Asia (e.g., Northwestern and Southwestern Tajikistan, and Uzbekistan) appear primarily on fluvial terraces (e.g., of the Zarafshan River), and their development is made possible by huge melioration networks. Without water supply they would not have been able to develop there due to the dominance of continental and subtropical climates (dry, and extremely dry, continental climates).

In other regions, factors other than climate may play crucial roles. For instance, land elevation and orography is important, as grapevines prefer slopes that face southwards or artificially shaped hillsides that are meant to provide Vitis vinifera subsp. sativa with the optimal conditions for growth. In cold habitats, grapevines are likely to be damaged by frost, and are also susceptible to pathogens.

These were the decisive factors for the grapevine domestication processes and the paths they took. Likewise, they still play crucial roles in the establishment of vineyards today.

However, other factors, beyond the natural ones, have also influenced further transformation of winery landscapes. These include:

- historical and political factors - Resorting to a huge generalization, these are, inter alia, expansions of certain cultures, wars, events resulting from new borders and administrative divisions, technological progress, establishment of influence zones in politics and administration with their accompanying legal systems which, since the time of the Roman Empire, have had crucial influences on changes in the reach of grapevine cultivation and the creation of winery regions (continuous, lasting landscapes) or their disappearance. Such factors have occurred frequently in historical times, and winery landscapes have gathered numerous layers, which has resulted in their metamorphoses. At present, such changes may be analyzed in detail through the reconstruction of the spatial organization features of certain venues or through the interpretation of landscape landmarks, that is, signs.

- economic factors - The most important of these seem to be special economic privileges for vineyards and for countries specializing in wine production, such as tariff and tax exemptions. Other factors, such as the presence of trade routes, the possibility for building and supervising wine storehouses, and trade monopolization, influenced the development of winery regions. Economic factors also refer to rich regions' potential to obtain new cultivation methods and techniques and gain access to new technologies protecting plants from diseases, as well as to the rules governing winemaking supervision. At present, specialist marketing and advertising should also be enumerated among such factors. The wine trade was influenced by new discoveries related to wine preservation, and additives including cedar oil, juniper sprigs, laurel leaves, pine needles, thyme, rosemary, absinthe, and even opium and hashish. In many Southern European countries, and primarily in Central Asia, owning a vineyard is still a status symbol and a prosperity indicator among given ethnic groups. A vineyard is affordable for big landowners who also produce other plants in their extensive fields.

- socio-economic factors - The most significant of these in the possible transformation of winery regions include systems and forms of ownership related to land and material goods as well as demographic changes (rising population density in a specific area). The preservation of old professions as well as the social, material and professional structures (wine-makers) characterizing inhabitants of a given area also play an important role. Socio-economic factors also include the susceptibility of certain societies to adopting wine consumption patterns typical of Western Europe (e.g., serving wine to accompany meals). Wine is becoming fashionable, and, in some countries, it is increasingly treated as an indicator of 'prestige lifestyle'. At the same time, consumers' awareness of the advantages of wine as an element of a healthy diet is rising. Fruit farmers, in turn, acquire more knowledge on viticulture thanks to the experience they gain through working in European wineries and through access to specialist literature, which is being published in increasing amounts (raising the overall level of agricultural expertise). Furthermore, more and more frequently (as is often the case with revitalized landscapes) fruit farmers search for new, alternative sources of income (the so-called economic niche) (Myśliwiec 2009).

As their ecological requirements are relatively modest, some Vitis species are planted to secure river banks and protect embankments from erosion. Alleys with grapevine architecture are also created in such places. Artificial structures constitute a support on which $V$. vinifera lianas are able to spread quickly, and their wide leaves form thick canopies that give protection from sunlight and provide cooling shade during hot summer days. - cultural factors - These result from the gradual cultural popularization of grapevine cultivation and improving patterns (models, directions) of cultivation. These factors also include specific vineyard architecture and facilities that have evolved over centuries, and typically comprise stone mansions (residences), wine cellars, storehouses, access roads highlighted by rows of cypresses, and oak trees or thujas. Such mansions constitute the contribution of many generations of winemakers to the shaping of the structure and physiognomy of the cultural landscape. Among cultural factors, local customs may also be distinguished, such as emphasizing ownership (e.g., with rosebushes of different colors) and traditions accompanying grape harvesting (e.g., special songs sung during harvesting, local legends). Wine-related customs and celebrations stem from preChristian times, dating back to ancient Greece (where the cult of wine reached its height with the Dionysia) and ancient Rome (the cult of Bacchus). Grapevine leaves and grapes are present as ornaments in the oldest paintings, drawings, and additionally, in architecture. The influence of non-material culture (celebrations, customs, legends, mythology, toponymy) on creating the symbols associated 
with winery landscapes is also notable. In Poland, cultural factors have contributed to the development of a toponymic layer of the landscape, for example, places such as Winary ${ }^{6}$, Winnica, Winogrady (Myśliwiec 2009). Some names that used to be familiar only to the native inhabitants of winery regions have entered the international vocabulary, for example, from Spanish (Bodega), from Italian (Azienda agricola, Azienda vinicola, Cantina), from French (Chateau, Clos, Cru classe, Domaine, Grand Cru, Premier cru), from German (Keller), from Czech (sklep), from Hungarian (szőlőskert), from Croatian (vinogorje, vinograd) etc.

In many countries in hot and dry zones, grapevines are grown to provide shade for houses, mansions, and public facilities, becoming an indispensable element of landscape design. For instance, in Tajikistan it is common to build special canopies that become grown over by grapevines, which spreads rapidly. It is, on the one hand, a decorative element, and on the other, a hideaway on hot days. The entrances to all public institutions in Tajikistan, and in particular in the Zerafshan Valley, are adorned with corridors (pergolas) formed by grapevines (Figure 4). It reflects the culture of the region, but, at the same time, there are no other plant species that would be equally resistant to extreme environmental conditions. Cultural factors also influence professional traditions and regional cuisine. Due to the diversity of climate and the wide range of grapevine varieties, in Tajikistan and partly also in Uzbekistan, grape harvesting starts in early July and lasts until the end of September (Figure 5, 6). Harvested grapes are mainly used for consumption, for export, and for alcohol production. An important part of harvesting is in drying the grapes next to vineyards in specially selected places with direct sunlight in order to obtain a number of resin varieties with seeds. During the whole harvesting period, grapes are to be found on every table and their consumption is very common. They are believed to have healing properties.

- religious factors - These have played a decisive role in specialization of certain grapevine strains and the purpose of cultivation. With the expansion of Christianity, Benedictine and Cistercian monks are believed to have been the precursors of viticulture in Europe since the Middle Ages. On farms next to their monasteries, they grew grapevines and made wine - mainly for the liturgy. In pre-Muslim times, wine was relatively popular in Arab countries. Islam brought restrictions that took the form of a total prohibition. It should be underlined that the ban on alcohol in Islam stems from social processes. Due to excessive alcohol consumption people lost control over their behavior and failed to participate in everyday prayers, which is required by the Quran. In addition, excessive alcohol consumption caused problems within families and societies. The ban was meant to deal with these problems and to protect Muslims. At the beginning of Islam's existence, some Muslims observed the ban very scrupulously, however, depending on the region, with time they began ignoring it; at present, the ban is not observed by everybody. Wine was served in the courts of Muslim rulers, particularly between 7 th and 10 th century, as a beverage from fermented grapes. Wine was also used by medieval Muslim medics (e.g., by Abu Ali Sina, widely known as Avicenna) as a healing substance, mixed with herbs (Azonzod 2010). Excellent Persian poets

${ }^{6}$ E.g., Winiary, a village in the province of Lesser Poland. Its name proves that grapevines were cultivated in Poland and wine was produced from grapes. This name first referred to the group of people who were employed in winemaking, servants of the local duke. Later on, this name was adopted by the village that they inhabited. Originally, the name had the form 'Winary' and was a derivative of old-Polish 'winarz', i.e., winemaker. First mentions of this village date back to the 13th century: Vinare, Winary, Winari (Malec 2003; Szczerbowska-Kopacz 2011).

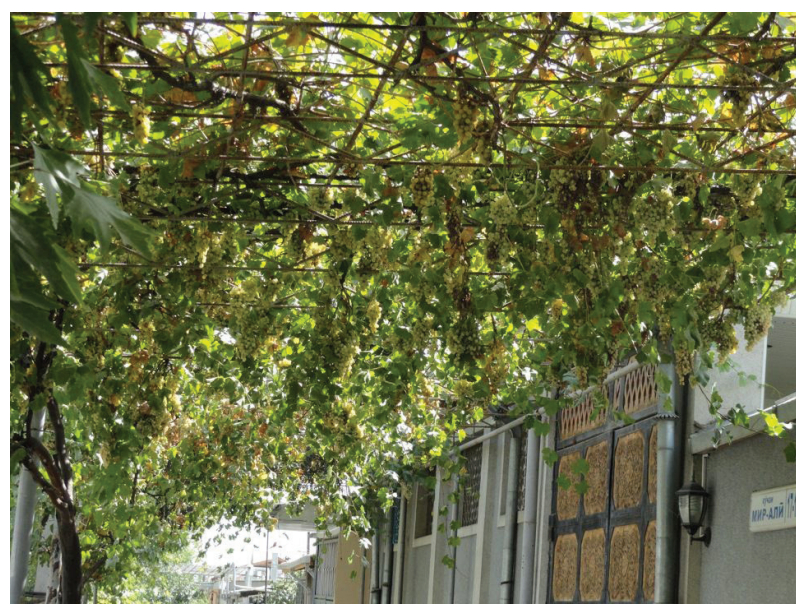

Figure 4. Vitis as a typical element of small architecture Southwestern Tajikistan, Photo: O. Rahmonov

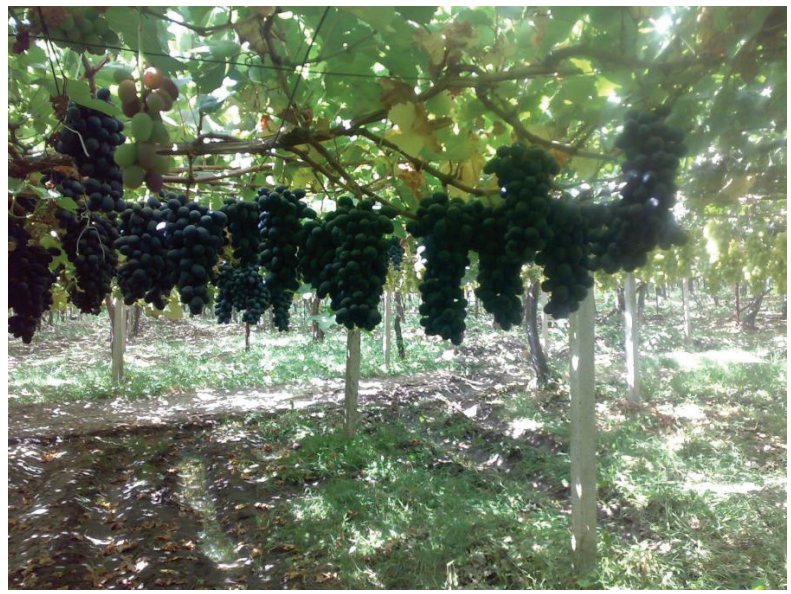

Figure 5. Ripening grapes, Southwestern Tajikistan, Photo: O. Rahmonov

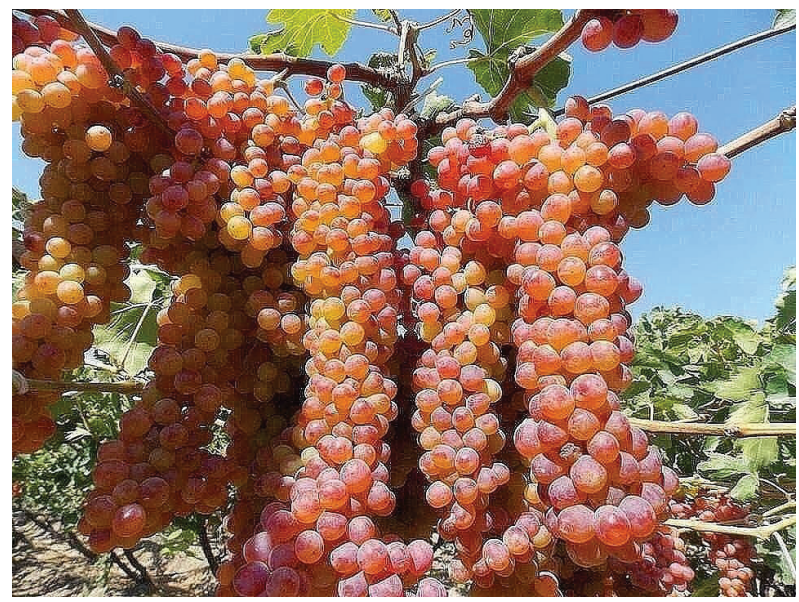

Figure 6. A dessert variety of grape, Southwestern Tajikistan, Photo: O. Rahmonov 
very often employed the word 'alcohol' with metaphorical meaning (as a beverage that 'makes [one] nobly happy' in everyday life). Among them were Omar Chajjam ( $11^{\text {th }} \mathrm{c}$.) coming from Avicenna's school; and the most distinguished Sufi poet, Persian mystic, and Islamic theologian, Jalāl adDīn Muhammad Balkhī (13th c.) - widely known as Rumi. Consequently, it can be shown that at the time this beverage was a symbol of mystical knowledge for members of mystic brotherhoods and for Sufis in general (Arberry 2009).

The symbolic attachment of Christianity to wine exerted a crucial influence on the development of grapevine cultivation in the Middle Ages. After the fall of the Roman Empire a rapid development in grapevine cultivation and winemaking is observable. It was the Catholic Church that played the main role in this process, particularly monks inhabiting various monasteries across Europe, which were very numerous at the time (Rekowski 2013).

This is how the culture of societies, based on specific preferences and attachment to traditions, that is, the unique genius loci of particular regions, emerged (Myga-Piątek 2012).

The coexistence and combined influence of the abovementioned local and regional factors constitute a system of multiple variables that are very difficult to interpret globally. This is why it was merely signaled here. A detailed discussion of these factors is only possible for particular winery regions and would require a deeper analysis (using the method of regional biography - Myga-Piątek 2012; Raszeja 2013).

\section{Existing winery landscapes}

The present distribution of the wild grapevine is highly fragmented, and can be found in disjoint micro-populations or metapopulations with few individuals, at least in the western part of the Mediterranean Basin (Terral et al. 2010). Regions in which extensive vineyards constitute a common landscape element at present, have emerged, mostly, as a result of conscious human activity. Forest and shrub biocenoses were replaced with agrocenoses of $V$. vinifera subsp. sativa, which has gradually become the dominant element of the cultural landscape. Consequently, such agrocenoses constitute a homotonic background that clearly stands out among other natural phytocenoses.

Anthropogenic pressure on their natural habitats, and pathogens introduced from North America during the second part of the 19th century, may explain the progressive decline of wild grape populations (Arnold et al. 1998) in several regions. The 'Phylloxera crisis' that affected European vineyards had a considerable impact on both cultivated varieties and wild grapes. As a result, modern wild grapevines are endangered throughout their distribution range and threatened with extinction (Arnold et al. 2005). Conservation efforts are required to maintain the genetic integrity and survival of the remnant populations (Bacilieri et al. 2013). The future of Vitis vinifera represents a major stake in biodiversity conservation.

In contrast to wild grapevines, the cultivated Vitis vinifera subsp. Sativa has today spread considerably thanks to human agricultural activity, with new winery regions emerging on all continents (Johnson \& Robinson 2008).

Current winery landscapes stem from the relatively narrow natural range of Vitis vinifera subsp. sylvestris. They are common nowadays in Southern Europe, stretching from the Spanish and French Atlantic Coast to certain regions of Western Asia (see Figure 1), that is the Near East, the Levant, Iran, the Transcaucasia, Uzbekistan, and Tajikistan (Zohary 1996); where the climate and other habitat conditions are favorable to grapevines.
The expansion of wild grapevines became possible during the warm period of the late Pleistocene (Komarov 1938). During the Neolithic, grapevines covered almost the same area as today, although climate diversity was less then.

\section{Forecasted landscapes}

In contemporary Europe, $V$. vinifera supsp. sativa is cultivated north of the natural range of Vitis vinifera L. subsp. sylvestris, and it has adapted very well to these climate conditions. Grapevines also produce fruit near the tropics, while in the Himalayas they are cultivated at high altitudes - up to $2,700 \mathrm{~m}$ above sea level. Consequently, in comparison with other species of the Vitis genus, the domesticated subspecies possesses a wide ecological amplitude and may be regarded as a eurytopic.

Winery landscapes expand in some regions while dwindling in others, which results from social needs and industrial demand. It should be emphasized that this process is typically observed within the natural range of the species. The populations that are isolated and scattered nowadays may gain greater cohesion over time due to changes in land use.

In some regions of Central Asia (e.g., in Tajikistan, the Zerafshan Valley), vineyards have been transformed into sunflower plantations for economic reasons. Consequently, some continuous winery landscapes may turn into isolated patches. In western Tajikistan, on the other hand, black-earth (Calcic Chernozem) is used to establish numerous new vineyards, so that grapevines cover increasing amounts of agricultural land.

Throughout the centuries, evolutionary cultural landscapes have been subject to rapid transformation resulting from, among other factors, urban sprawl and the dispersion of housing into open areas; increased mass commercial tourism and the socalled tourist colonization; and a change in traditional forms of land management into industrialized agriculture, that is, high technology agriculture (Myga-Piatek 2008). In the future, the development of winery landscapes worldwide will depend primarily on financing and the degree of commercialization of winery areas (competition among winery regions). Due to the changing climate (water deficits), in areas with an arid or semiarid climate, the availability of irrigation systems will play a decisive role. Moreover, if grapes and their derivatives are difficult to introduce into markets, this may result in farmers giving up production and, consequently, in the disappearance of winery landscapes. Winery landscapes should play an important public role in cultural, economic, ecological and social fields. They create a resource for economic activity, stimulate new jobs, create a recognizable image for regions, and contribute to the development of tourism. The successful development of vineyards and viticulture in many places around the world testifies to the important role of governmental support, such as preferential taxation, or the financing of marketing activities and scientific research aimed at improving grape quality.

Winery tourism may well meet the requirements for, so-called, sustainable tourism (Myga-Piatek 2011). This will only become possible, however, with optimal management. The planning and organization of grape cultivation and wine production must constitute an integral part of the development policies that are implemented by individual regions. Another necessary element is the creation and implementation of a model of partnership between the public and the private sectors, which should intend to prevent the negative results of globalization processes and small vineyards being pushed out of the market. Whereas in the recent past, viticulture was limited to traditional family businesses, now it has spread to cover large areas and in many regions it already resembles mass agriculture. 


\section{Conclusion}

Cultural landscapes have emerged from the historical process of human culture acting upon natural landscapes. They comprise many subtypes that differ according to their origin, structure, functions, and their dominant shaping factors. From the point of view of landscape physiognomy, this is reflected in specific spatial organization characteristics for a given landscape type (Myga-Piątek 2008, 2012). Regionally, a landscape may be defined as a fragment of geographical space whose structure and functions have emerged due to a combination of natural and cultural processes and components, resulting in a specific spatial organization that determines the physiognomic distinctiveness of a region.

Winery landscapes are a subtype of the agricultural landscape, which constitute one of the oldest types of cultural landscapes. The structure of a winery landscape, seen as a way of placing, organizing and giving a hierarchy to a landscape's elements as well as the connections among the constituent parts (layout, composition, and configuration of structural elements of a winery landscape); is highly specific. Inter alia, winery landscapes are distinguishable through their largely geometric field layout, which results from the specificity of cultivated grapevines, from the location and shape of grapevine patches, and, increasingly, also from mechanized agriculture methods.

Our analysis of the evolution of winery regions shows that these landscapes belong to the oldest cultural landscapes in the world. In many places, they have already disappeared and replaced by other cultural landscape types and subtypes - the so-called landscape stratigraphy (Myga-Piątek 2012). At present, the reach of winery landscapes has increased considerably. Winery microregions are to be found far from the contiguous range of the grapevine. Increasingly often, vineyards are established in areas with poorer soils. Due to their resistance to water deficits and strong sunshine, grapevines may be cultivated in very sunny areas. Viticulture defines the environmental conditions of a specific vineyard as terroir (Seguin 1986; Sommers 2008). The places where grapevines are cultivated exert significant influence on the growth and fruit production of plants, but it also determines the future taste of the local wine. This is why grapevines are so closely connected with the area in which they grow, and place of origin is one of the most important determinants of a wine.

Winery landscapes as a form of cultural landscape constitute the heritage of individual regions, as they document, in geographical space, the activities of societies across many historical epochs, and the combined influence of very numerous interlinked factors. Consequently, they provide evidence of local traditions and identities, of societies' attachment to a specific place. Highly specialized, ancient winery regions testify to the durability of specific land use and to the so-called 'landscape memory' (Myga-Piątek 2015).

The history of grapevine domestication is very long and complex. At the same time, it illustrates, with much detail, the life history of the Vitis species. Humans have developed and improved a wide range of varieties, which are famous under their own names, in various regions of the world. The beginnings of global viticulture have been scrutinized by various scientific disciplines, and the history of Vitis vinifera has been thoroughly studied by genetics (Pipia et al. 2014). Analyses of genetic material and other research has enabled scientists to explain the emergence and mechanisms of domestication, hybridization, and spread of grapevines. This holistic approach facilitates our understanding of the history of Vitis vinifera subsp. sativa - a truly amazing subspecies.

\section{References}

Arberry, AJ 2009, Mystical Poems of Rumi, University of Chicago, Press, ( $3^{\text {rd }}$ ed.) Chicago.

Arroyo-García, RA \& Revilla, E 2013, 'The Current Status of Wild Grapevine Populations (Vitis vinifera ssp sylvestris) in the Mediterranean Basin' in Agricultural and Biological Sciences - The Mediterranean Genetic Code - Grapevine and Olive, eds D Poljuha \& B Sladonja. DOI: 10.5772/52933.

Arnold, C, Gillet F \& Gobat, JM 1998, 'Situation de la vigne sauvage Vitis vinifera ssp.silvestris en Europe', Vitis, vol. 37(4), pp. 159-170.

Arnold, C, Schnitzler, A, Douard, A, Peter, R \& Gillet, F 2005, 'Is there a future for wild grapevine (Vitis vinifera subsp. silvestris) in the Rhine Valley?', Biodiversity \& Conservation, vol. 14, no. 6, pp. 1507-1523. DOI: 10.1007/s10531-004-9789-9.

Arrigo, N \& Arnold, C 2007, 'Naturalised Vitis rootstocks in Europe and consequences to native wild grapevine', PLos One, vol. 2. Available from: <https://doi.org/10.1371/journal. pone.0000521 >. [5 January 2018].

Azonzod, Dz 2010, The medicine and food plants. Adib, Dushanbe.

Bacilieri, R, Lacombe, T, Le Cunff, L, Di Vecchi-Staraz, M, Laucou, V, Genna, B, Péros, JP, This, \& Boursiquot, JM 2013, 'Genetic structure in cultivated grapevines is linked to geography and human selection', BMC Plant Biology", no 8 , pp. 13-25. DOI: 10.1186/1471-2229-13-25.

Bokwa, A \& Klimek, M 2009, 'Warunki klimatyczne Pogórza Wielickiego dla potrzeb uprawy winorośli' in Człowiek i rolnictwo, ed. A Zborowski \& Z Górka, Instytut Geografii Gospodarki Przestrzennej Uniwersytet Jagielloński, Kraków, pp. 103-111.
Bouby, L \& Marinval, P 2001, La vigne et les débuts de la viticulture en France: apports de l'archéobotanique', Gallia, vol. 58, pp. 13-28.

Bosak, W 1998, Możliwości uprawy winorośli w regionie Jury Krakowskiej, Ojcowski Park Narodowy, Ojców.

Bosak W 2004, Uprawa winorośli i winiarstwo w małym gospodarstwie na Podkarpaciu, Związek Gmin Dorzecza Wisłoki, Jasło.

Bosak W 2006, Winorośl i wino w małym gospodarstwie $w$ Małopolsce, Małopolska Agencja Rozwoju Regionalnego S.A., Kraków.

Bosak, W 2013, Przewodnik po małopolskich winnicach. Available from: <http://www.wiktor.ch/wp-content/uploads/2014/01/ malopolski szlak winny.pdf>. [19 December 2017].

Braudel, F 2004, Morze Śródziemne i świat śródziemnomorski w epoce Filipa II, Wydawnictwo Książka i Wiedza, Warszawa.

Chmielewski, JT, Myga-Piątek, U \& Solon, J 2015, 'Typologia krajobrazów aktualnych', Polski Przegląd Geograficzny', vol. 87, no 3, pp. 377-408.

Crespan, M 2004, 'Evidence on the evolution of polymorphism of microsatellite markers in varieties of Vitis vinifera L.', Theoretical and Applied Genetics, vol. 108, pp. 231-237.

Desfayes, M 1989, ,La vigne sauvage en Valais', Bulletin Murithienne, vol. 107, pp. 161-165.

Góralczyk, A 2016, 'Witis vinifera sylvestris i Witis vinifera sativa. Udomowienie i upowszechnienie się uprawy winorośli w starym świecie na podstawie badań archeologicznych i paleobotanicznych', Folia praehistorica posnaniensia, vol. XXI, Instytut Archeologii, UAM Poznań, pp. 123-148. DOI.ORG/10.14746 
Grąbczewski, B 2010, Podróże po Azji Środkowej 1885-1890, Wydawnictwo Naukowe PWN SA, Warszawa.

Heaton, E \& Merenlender, AM 2000, 'Modeling vineyard expansion, potential habitat fragmentation', California Agriculture, vol. 54, pp. 12-19.

Henry Architects 2017. Available from: <http://henryarchitects. com.au/projects/landscape/winery-landscaping/>. December 2017].

Heywood, V \& Zohary, D 1991, 'A catalogue of wild relatives of cultivated plants native to Europe', Flora Mediterranea, vol. 5, pp. 375-415

Jackson, R 2008, Wine science, Principles and applications, Academic Press, Amsterdam.

Jacquat, Ch 1988, 'Les plantes de l'âge du Bronze: catalogue des fruits et graines', Hauterive-Champréveyres vol. 1; Archéologie neuchâteloise no. 7, Saint-Blaise.

Joffe, A 1998, 'Alcohol and social complexity in Ancient western Asia', Current Antropology, vol. 39 (3), p. 297-322.

Johnson, H \& Robinson, J 2008, Wielki atlas świata win 2008, Buchmann.

Komarov, VL 1938, Proishoždenie kull'turnyh rastenij. Izbrannye sočineniâ, vol. 12, Moskva, Leningrad.

Mangafa, M \& Kotsakis, K 1996, 'A New Method for the Identification of Wild and Cultivated Charred Grape Seeds', Journal of Archaeological Science, vol. 23, pp. 409-418.

McGovern, PE 2003, Ancient Wine. The Search for the Origins of Viniculture, Princeton, Princeton University Press.

Mc Govern, PE, Glusker, DL, Exener, LJ \& Voigt, MM 1996, 'Neolithic resin wine', Nature, vol. 381, pp. 480-481.

Myles, S, Boyko, AR, Owens, C, Brown, C, Grassi, F, Aradhya, MK, Prins, B, Reynolds, A, Chia, JM, Ware D, Bustamante, CD \& Buckler, E 2011, 'Genetic structure and domestication history of the grape', Proceedings National Academic of Science USA, vol. 108, (9), pp. 3530-3535.

Levadoux, L 1956, 'Les populations sauvages et cultives de Vitis vinifera L.', Annales de l'almélioration des plantes, vol. 1, pp. 59-117.

Malec, M 2003, Słownik etymologiczny nazw geograficznych Polski, Wydawnictwo Naukowe PWN, Warszawa.

Myśliwiec, R 2009, Uprawa winorośli, Wydawnictwo Plantpress, Kraków.

Myga-Piątek, U 2008, 'Between tradition and modernity of the cultural landscape research. Discussion on methodology', Dissertations Commission of Cultural Landscape, (Prace Komisji Krajobrazu Kulturowego), no. 9, pp. 75-91.

Myga-Piątek, U 2011, 'Cultural landscape of 21 century. Geographical consideration between theory and practice' Croatian Geographical Bulletin, vol. 73, no 2, pp. 129-140.

Myga-Piatek, U 2012, Krajobrazy kulturowe. Aspekty ewolucyjne i typologiczne, University of Silesia, Katowice (in polish with English abstract).

Myga-Piątek, U 2015, 'Pamięć krajobrazu - zapis dziejów w przestrzeni', Studia Geohistorica, no. 3, pp. 31-47.

Myga-Piątek, U, Chmielewski, TJ \& Solon, J 2015, 'Rola cech charakterystycznych, wyróżników i wyznaczników krajobrazu w klasyfikacji i audycie krajobrazów aktualnych', Problemy Ekologii Krajobrazu, vol. 40, pp. 177-185.

Nuñez-Rivera, D \& Walker, MJ 1989, 'A review of paleobotanical findings of early Vitis in the Mediterranean and of the origins of cultivated grape-vines, with special reference to new pointers to prehistoric exploitation in the western Mediterranean', Review of Paleobotany and Palynology, vol. 61, pp. 205-237.

Negrul, AM 1946, 'Proishoždenie kullturnogo vinograda $i$ ego klassifikaciâ', Ampelografiâ SSSR, vol. 1, Moskva
Olmo, HP 1996, 'The Origin and Domestication of the Vinifera Grape' in The Origins and Ancient History of Wine, eds PE McGovern, SJ Fleming \& SH Katz, Amsterdam, Routledge, pp. 31-43.

Ovčinnikov, PN (ed.) 1981, Flora Tadžickoj SSR, LeningradMoskva, Izdatel'stvo Nauka, vol. I-VI.

Pipia, I, Gamkrelidze, M, Gogniashvili \& M, Tabidze, V 2014, 'Genetic diversity of Georgian varieties of Vitis vinifera subsp. Sylvestris', Genetic Resources and Crop Evolution, vol. 61, pp. 1507-1502. DOI: 10.1007/s10722-014-0125-2.

Plit, F 2011, Krajobraz kulturowy - czym jest, Wydawnictwo Wydziału Geografii i Studiów Regionalnych, Uniwersytet Warszawski, Warszawa.

Plit, F 2016, Krajobrazy kulturowe w geografii polskiej, Szkice, Wydawnictwo Dialog, Warszawa.

Przybek, P 2017, Mapa 415 polskich winnic. Available from: <http://winogrodnicy.pl/>. [20 December 2017].

Raszeja, E 2013, Ochrona krajobrazu w procesie przekształceń obszarów wiejskich, Wydawnictwo Uniwersytetu Przyrodniczego w Poznaniu, Poznań

Rahmonov, O, Rahmonov, M, Opała-Owczarek, M, Owczarek, P, Niedźwiedź, T \& Myga-Piątek, U 2017, 'Ecological and cultural importance of juniper ecosystem in the area of Zeravshan valley (Tajikistan) on the background of environmental condition and anthropogenic hazards', Geographica Polonica, vol. 90 (4), pp. 441-461.

Rahmonov, O, Szczypek, T, Niedźwiedź, T, Myga-Piątek, U, Rahmonov, M \& Snytko, VA 2017, 'The human impact on the transformation of juniper forest landscape in the western part of the Pamir-Alay range (Tajikistan)', Environment Earth Science, vol. 76 (8). DOI 10.1007/s12665-017-6643-4.

Renfrew, JM 1996, 'Palaeoethnobotanical Finds of Vitis from Greece' in The Origins and Ancient History of Wine Amsterdam, eds PE McGovern, SJ Fleming \& SH Katz, Routledge, pp. 255-267.

Seguin, G 1986, '"Terroirs” and pedology of wine groving', Experientia, vol. 42.

Sommers, BJ 2008, The geography of wine, A Plume Book, New York.

Szczerbowska-Kopacz, J 2011, 'Klasyfikacja, znaczenie oraz pochodzenie nazw geograficznych w Polsce', Językoznawstwo: współczesne badania, problemy $i$ analizy językoznawcze, vol. 5, pp. 177-184.

Stummer, A, 1911, 'Zur Urgeschichte der Rebe und des Weinbaues', Mitteilungen der Anthropologischen Gesellschaft in Wien, vol. 61, pp. 283-296.

Terral, JF, Tabard, E, Bouby, L, Ivorra, S, Pastor, T, Figueiral, I, Picq, S, Chevance, JP, Jung, C, Fabre, L, Tardy, Ch, Compan, M, Bacilieri, R \& Lacombe, T, This, $P$ 2010, 'Evolution and history of grapevine (Vitis vinifera) under domestication: new morphometric perspectives to understand seed domestication syndrome and reveal origins of ancient European cultivars', Annals of Botany, vol. 105, pp. 443-455.

This, P, Lacombe, T \& Thomas, MR 2006, 'Historical origins and genetic diversity of wine grapes', Trends in Genetics, vol. 22 (9), pp. 511-9.

World Landscape Architect 2017. Available from: <http:// worldlandscapearchitect.com/swa-group-designs-napawinery-integrating-infrastructure-while-preserving-thenatural-landscape/\#.WkYFXdiWxR0>. [19 December 2017].

WRB, 2006, World reference base for soil resources 2006, World Soil Resources Reports No. 103. FAO, Rome.

Zettler, RL \& Miller, NF 1996, 'Searching for Wine in the Archaeological Record of Ancient Mesopotamia of the Third 
and Second Millennia B.C.' in The Origins and Ancient History of Wine, ed PE McGovern, SJ Fleming \& SH Katz, , Amsterdam, Routledge pp. 123-131.

Zinelabine, LH, Haddioui, A, Bravo, G, Arroyo-Garcia, R \& Martinez-Zapater, JM 2010, 'Genetic origins of cultivated and wild grapevines from Morocco', American Journal of Enology and Viticulture, vol. 61 issue 1, pp. 83-90.

Zohary, D 1996, 'The Domestication of the Grapevine Vitis Vinifera L. In the Near East' in The Origins and Ancient History of Wine Amsterdam: Routledge, eds PE McGovern, SJ Fleming \& SH Katz, pp. 23-30. 